Original Article

\title{
Expectations from Rehabilitation of Children with Cerebral Palsy: The Agreement between the Physiotherapists and Mothers
}

\author{
ErdoĞan Kavlak, PT, PhD ${ }^{1)^{*}}$, Filiz AltuĞ(1), UĞUr Cavlak ${ }^{1)}$, Havva Aylin Kavlak ${ }^{2)}$, \\ HANDE ŞENOL ${ }^{3)}$ \\ 1) School of Physical Therapy and Rehabilitation, Pamukkale University: Kınıklı Kampüsü Rektörlük \\ Binası Zemin kat, 20070 Denizli, Turkey \\ 2) Yă̆mur Çocukları Special Education and Rehabilitation Center, Turkey \\ 3) Pamukkale University Faculty of Medicine Department of Biostatistics, Turkey
}

\begin{abstract}
Purpose] The aim of this study was to examine the agreement between physiotherapists (PTs) and mothers (Ms) about the treatment of children with cerebral palsy (CP) who received treatment in special education and rehabilitation centers. [Subjects] Ms of 130 children with CP (75 boys, 55 girls) and 130 PTs who applied rehabilitation programs were interviewed. [Methods] Clinical types and gross motor function levels of the children were recorded. A questionnaire consisting of 6 open-ended questions was used to describe the expectations and views of the PTs and Ms about the physiotherapy and rehabilitation programs for the children. [Results] The mean age of the children was $89.80 \pm 52.05$ months. The mean treatment period for the children was $73.62 \pm 42.11$ months. The mean age of the mothers was $35.47 \pm 5.79$ years, and the mean age of the PTs was $28.07 \pm 7.28$ years. We found a statistically moderate level of agreement between the PTs and Ms regarding the appropriateness of the treatment provided to the children. There was statistically insignificant agreement regarding the applied treatment methods and the appropriateness of the applied rehabilitation programs. [Conclusion] We believe that the views and expectations of the Ms should be taken into account by the PTs when preparing a treatment program for children with CP.

Key words: Cerebral palsy, Physiotherapist, Mother
\end{abstract}

(This article was submitted Jan. 14, 2014, and was accepted Feb. 16, 2014)

\section{INTRODUCTION}

Rehabilitation for the cerebral palsied children should be given thought a team work including parents as a model refers to patient centered treatment regimens ${ }^{1-3)}$.

This idea encourages considering parent's opinions about physiotherapy and rehabilitation for their children with CP. For this reason, health providers, especially physiotherapists (PTs), should talk with the parents of a disabled child before planning a specific treatment or intervention in order to establish the most suitable program for the child ${ }^{4-7)}$.

The parents of disabled children seek to learn all details, both positive and negative aspects, about a physiotherapy and rehabilitation program that will be applied to their children. This is necessary for the parents to understand the mission and goal of the program. Moreover, the PTs and mother (M) or father of a disabled child should evaluate the child together so that they can define the needs of the child. For this reason, the parents of children with $\mathrm{CP}$ should also

*Corresponding Author. Erdoğan Kavlak (E-mail: kavlake@ hotmail.com)

C2014 The Society of Physical Therapy Science. Published by IPEC Inc. This is an open-access article distributed under the terms of the Creative Commons Attribution Non-Commercial No Derivatives (by-ncnd) License $<$ http://creativecommons.org/licenses/by-nc-nd/3.0/>. be included in making decisions in the rehabilitation process $^{4,5,8,9)}$

The purposes of this research were (1) to understand perceptions of Ms and PTs regarding the rehabilitation programs their children receive and (2) to report the current knowledge of Ms and PTs, highlighting consensus and disagreement.

\section{SUBJECTS AND METHODS}

The study was conducted between January and April 2012. One hundred and thirty children ( 75 boys, 55 girls) who were being treated in special education centers in different parts of Turkey and their Ms and 130 PTs who were treating them were included in the study.

Informed consent was obtained from Ms and PTs, written approval was obtained for the study from the managers of the schools, and the study was completed in accordance with the principles of the Helsinki Declaration.

The inclusion criteria were as follows: all participants agreed to participate, the children had been diagnosed with $\mathrm{CP}$ by a pediatric neurologist, and the caregivers of the children had to be Ms.

Demographic data of children, Ms, and PSTs were recorded.

The Gross Motor Function Classification System (GM- 
FCS) was used to determine the functional level appropriate for the age of the child and score it between 1 and 5. While a score of 1 indicates that the child may easily achieve indoor ambulation without the need for adjunctive mobilization devices, a score of 5 indicates that the child is totally dependent for mobilization. The reliability and validity of the classification system have been determined for children aged between 2 months and 12 years, and studies have also been done for adults with $\mathrm{CP}^{10,11)}$

The questionnaire form was composed of 6 open-ended questions asking about the expectations and opinions of the Ms and PTs with regard to the physiotherapy and rehabilitation programs being used. The questionnaire form was created by experienced PTs who were working in the pediatric rehabilitation units of university hospitals and special education rehabilitation centers.

In the present study, power analysis revealed that $90 \%$ power would be obtained with a reliability of $95 \%$ if 130 people were included in the study. SPSS 18.0 was used for data analysis. Characteristics of the children with $\mathrm{CP}, \mathrm{Ms}$, and PTs are presented as mean \pm standard deviation, numbers, and percentages. The views of the PTs and Ms are presented as numbers and percentages. The level of statistical significance was set at $\mathrm{p}<0.05$. The kappa coefficient $(\mathrm{K})$ was used to analyze agreement with regard to the views of the PTs and Ms. The kappa coefficient ranged between 0 and 1. A kappa coefficient for two values of between 0.0 and 0.20 was considered to indicate statistically insignificant concordance, and one between 0.21 and 0.40 was considered to indicate statistically moderate concordance.

\section{RESULTS}

The mean age of the children who participated in the study ( 75 boys, 55 girls) was $89.80 \pm 52.05$ months, and the mean duration of treatment was $73.62 \pm 42.11$ months. The mean age of the Ms was $35.47 \pm 5.79$ years. The mean age of the PTs was $28.07 \pm 7.28$ years, and their mean number of working years was $6.84 \pm 7.51$. Of the Ms, $83.1 \%$ had 12 years or less of education, $14.6 \%$ had 12 or more years of education and $2.3 \%$ were illiterate (Table 1 ). The distribution of clinical types of $\mathrm{CP}$ cases and levels according to the GMFCS are shown in Table 1.

According to the results of the questionnaire that asked about the opinions of the Ms and PTs, while $33.1 \%(n=43)$ of the PTs and $32.3 \%(n=42)$ of the Ms defined the health status of the children as "good", the concordance was found to be $13.1 \%$. In addition, while $38.5 \%(\mathrm{n}=50)$ of the PTs and $39.2 \%(n=51)$ of the Ms defined the health status of the children as "moderate", the concordance was found as $18.5 \%$. Statistically insignificant correlation was found $(\mathrm{K}=0.129$ and $\mathrm{p}=0.015$ ) (Table 2).

When the awarenesses of the Ms and PTs about the therapies the children received were analyzed, $86.9 \%(n=113)$ of the PTs and $40 \%(n=52)$ of the Ms stated that the children were receiving Bobath therapy, and the concordance was found to be $36.2 \%$. Statistically insignificant concordance was found between the Ms and PTs $(\mathrm{K}=0.077$ and $\mathrm{p}=0.016)$ (Table 2).
Table 1. Characteristics of the children with CP, Ms, and PTs

\begin{tabular}{|c|c|c|}
\hline Children with $\mathrm{CP}$ & $\mathrm{X} \pm \mathrm{SD}$ & Min-Max \\
\hline Age (months) & $89.80 \pm 52.05$ & $18-300$ \\
\hline Treatment period (months) & $73.62 \pm 42.11$ & $18-240$ \\
\hline Gender & $\mathrm{n}$ & $\%$ \\
\hline Boys & 75 & 57.70 \\
\hline Girls & 55 & 42.30 \\
\hline Mother & $\mathrm{X} \pm \mathrm{SD}$ & Min-Max \\
\hline Age (years) & $35.47 \pm 5.79$ & $23-49$ \\
\hline Physiotherapist & $\mathrm{X} \pm \mathrm{SD}$ & Min-Max \\
\hline Age (years) & $28.07 \pm 7.28$ & $22-51$ \\
\hline Length of service (years) & $6.84 \pm 7.51$ & $1-30$ \\
\hline Education level of mother & $\mathrm{n}$ & $\%$ \\
\hline 12 years or less & 108 & 83.1 \\
\hline 12 years or more & 19 & 14.6 \\
\hline Illiterate & 3 & 2.3 \\
\hline $\begin{array}{l}\text { Clinical types of the children } \\
\text { with } \mathrm{CP}\end{array}$ & $\mathrm{n}$ & $\%$ \\
\hline Spastic & 111 & 85.4 \\
\hline Dyskinetic & 7 & 5.4 \\
\hline Ataxic & 6 & 4.6 \\
\hline Hypotonic & 4 & 3.1 \\
\hline Mixed type & 2 & 1.5 \\
\hline \multicolumn{3}{|l|}{ GMFCS } \\
\hline Level 1 & 10 & 7.7 \\
\hline Level 2 & 21 & 16.2 \\
\hline Level 3 & 38 & 29.2 \\
\hline Level 4 & 36 & 27.7 \\
\hline Level 5 & 25 & 19.2 \\
\hline
\end{tabular}

While $94.6 \%(n=123)$ of the PTs and $83.1 \%(n=108)$ of the Ms stated that they found the therapy appropriate, the concordance was found to be $82.3 \%$. Moderate concordance was found between the PTs and Ms when all answers about the appropriateness of therapy were evaluated $(\mathrm{K}=0.338$ and $\mathrm{p}=0.0001)$ (Table 2).

When asked about the ability to walk with/without help, $31.5 \%(n=41)$ of the PTs and $38.5 \%(n=50)$ of the Ms stated that they wanted the children with $\mathrm{CP}$ to walk with/without help, and the concordance was found to be $17.7 \%$. Statistically insignificant concordance was found between the PTs and Ms when all expectations were evaluated $(\mathrm{K}=0.187$ and $\mathrm{p}=0.0001)($ Table 3$)$.

When asked about additional therapy, $18.5 \%(n=24)$ of the PTs and $32.3 \%(n=42)$ of the Ms stated that it was not necessary. The concordance was found to be $6.2 \%$. Statistically insignificant concordance was found between the PTs and $\mathrm{Ms}$ with regard to additional therapies $(\mathrm{K}=0.136$ and $\mathrm{p}=0.001)$ (Table 3).

Finally, when questioned about the efficacy of the physiotherapy and rehabilitation programs, $25.4 \%(n=33)$ of the PTs and $30.8 \%(n=40)$ of the Ms defined the applied therapy as "very good", and the concordance was found to be $10.0 \%$. Statistically insignificant concordance was found between the PTs and Ms in terms of opinions about the efficacy of 
Table 2. Description of the health of the children with CP, awareness about the received treatments, and views about the appropriateness of the treatments

\begin{tabular}{|c|c|c|c|c|c|c|}
\hline \multirow[b]{2}{*}{$\begin{array}{l}\text { Description of the health of the } \\
\text { children with CP* }\end{array}$} & \multicolumn{2}{|c|}{ Physiotherapist } & \multicolumn{2}{|c|}{ Mother } & \multicolumn{2}{|c|}{$\begin{array}{l}\text { Physiotherapist- } \\
\text { mother agreemen }\end{array}$} \\
\hline & $\mathrm{n}$ & $\%$ & $\mathrm{n}$ & $\%$ & $\mathrm{n}$ & $\%$ \\
\hline Perfect & 4 & 3.1 & 3 & 2.3 & 1 & 0.8 \\
\hline Very good & 12 & 9.2 & 13 & 10.0 & 1 & 0.8 \\
\hline Good & 43 & 33.1 & 42 & 32.3 & 17 & 13.1 \\
\hline Moderate & 50 & 38.5 & 51 & 39.2 & 24 & 18.5 \\
\hline $\mathrm{Bad}$ & 21 & 16.2 & 21 & 16.2 & 7 & 5.4 \\
\hline \multicolumn{7}{|l|}{$\begin{array}{l}\text { Awareness about the received } \\
\text { therapies* }\end{array}$} \\
\hline Bobath & 113 & 86.9 & 52 & 40.0 & 47 & 36.2 \\
\hline Vojta & 2 & 1.5 & 4 & 3.1 & 1 & 0.8 \\
\hline Special education & 5 & 3.8 & 50 & 38.5 & 4 & 3.1 \\
\hline Reflexology & 5 & 3.8 & 4 & 3.1 & 2 & 1.5 \\
\hline Botox & 3 & 2.3 & 2 & 1.5 & - & - \\
\hline I have no idea & 2 & 1.5 & 18 & 13.8 & - & - \\
\hline \multicolumn{7}{|l|}{$\begin{array}{l}\text { Views about the appropriateness } \\
\text { of the treatment** }\end{array}$} \\
\hline Yes & 123 & 94.6 & 108 & 83.1 & 107 & 82.3 \\
\hline No & 3 & 2.3 & 9 & 6.9 & 3 & 2.3 \\
\hline I have no idea & 4 & 3.1 & 13 & 10.0 & 2 & 1.5 \\
\hline
\end{tabular}

Table 3. The views of the physiotherapists and the mothers about the expectations from the treatment the children with $\mathrm{CP}$ receive, additional therapies and effectiveness of the physiotherapy and rehabilitation program

\begin{tabular}{|c|c|c|c|c|c|c|}
\hline \multirow[b]{2}{*}{ Expectations from the treatment** } & \multicolumn{2}{|c|}{ Physiotherapist } & \multicolumn{2}{|c|}{ Mother } & \multicolumn{2}{|c|}{$\begin{array}{l}\text { Physiotherapist- } \\
\text { mother agreement }\end{array}$} \\
\hline & $\mathrm{n}$ & $\%$ & $\mathrm{n}$ & $\%$ & $\mathrm{n}$ & $\%$ \\
\hline Walking with/without help & 41 & 31.5 & 50 & 38.5 & 23 & 17.7 \\
\hline Standing with/without help & 15 & 11.5 & 8 & 6.2 & 4 & 3.1 \\
\hline Sitting with/without help & 31 & 23.8 & 13 & 10.0 & 8 & 6.2 \\
\hline Independency in daily life activities & 20 & 15.4 & 46 & 35.4 & 8 & 6.2 \\
\hline Increased balance and postural control & 23 & 17.7 & 13 & 10.0 & 5 & 3.8 \\
\hline \multicolumn{7}{|l|}{ Additional therapies** } \\
\hline Not necessary & 24 & 18.5 & 42 & 32.3 & 8 & 6.2 \\
\hline Speech therapy & 34 & 26.2 & 37 & 28.5 & 14 & 10.8 \\
\hline Water exercise & 23 & 17.7 & 24 & 18.5 & 9 & 6.9 \\
\hline Special education and psychosocial support & 20 & 15.4 & 14 & 10.8 & 6 & 4.6 \\
\hline Reflexology & 12 & 9.2 & 5 & 3.8 & 2 & 1.5 \\
\hline Vojta & 3 & 2.3 & 3 & 2.3 & - & - \\
\hline Surgical & 5 & 3.8 & 3 & 2.3 & - & - \\
\hline Sensory-perception motor education & 9 & 6.9 & 2 & 1.5 & - & - \\
\hline \multicolumn{7}{|l|}{$\begin{array}{l}\text { Effectiveness of the physiotherapy and } \\
\text { rehabilitation program** }\end{array}$} \\
\hline Perfect & 13 & 10.0 & 12 & 9.2 & 3 & 2.3 \\
\hline Very good & 33 & 25.4 & 40 & 30.8 & 13 & 10.0 \\
\hline Good & 69 & 53.1 & 59 & 45.4 & 35 & 26.9 \\
\hline Moderate & 10 & 7.7 & 11 & 8.5 & 2 & 1.5 \\
\hline Bad & 5 & 3.8 & 8 & 6.2 & 3 & 2.3 \\
\hline
\end{tabular}

$* *$ Statistically significant $(\mathrm{p}<0.01)$, kappa coefficient 
the programs $(\mathrm{K}=0.141$ and $\mathrm{p}=0.009)$ (Table 3$)$.

\section{DISCUSSION}

The results of our study showed that while statistically insignificant concordance $(\mathrm{K}=0.0-0.20)$ was found between the PTs and Ms regarding the definition of the health statuses of the children, treatment methods applied to the children, required additional therapies, and appropriateness of the rehabilitation programs, statistically moderate concordance was found regarding the appropriateness of the therapies $(\mathrm{K}=0.21-0.40)$.

For families with a disabled child, it is quite difficult to accept the disability and rearrange lifestyles to adapt to the child's condition ${ }^{12-14)}$.

Ms who are the primary caregivers of disabled children and interact more often with them represent a risk group for mental health due to anxiety and worries about the problems of their disabled child ${ }^{15,16)}$. The significance of participation of the family in treatment and education of a disabled child is emphasized in the literature ${ }^{17-19)}$.

It has been emphasized that early application of physiotherapy to a child with $\mathrm{CP}$ are important for motor development of the child and that the mother perceives the condition of the child ${ }^{20)}$. Considering that all rehabilitation processes should be realized in the natural environment of the child, involving the family in this process is inevitable. Informing the family about the care and rehabilitation of the child and providing help are as effective as directly educating the child ${ }^{21}$. According to the results of our study, we consider that it is necessary to increase the contribution of mothers to treatment, to educate them in order to apply the therapies at home and to better understand their children, and to increase the cooperation with PTs.

In a study of Karaduman et al., families graded the treatment methods applied to their children as special education, physiotherapy, speech therapy, drug therapy, and surgical therapies, respectively ${ }^{22}$.

In our study, the mothers stated that Bobath therapy and special education treatment were the most appropriate and most beneficial treatment types for their children. Low concordance was found between PTs and Ms in terms of the therapies applied to the children and degree of benefit from treatment.

In the study of Karaduman et al., the outcomes expected by families from treatment were attainment of the most efficient level of the disability or total elimination of the disability ${ }^{22}$. In our study, $38.5 \%$ of Ms wanted their children to walk with/without help, and $35.4 \%$ wanted their children to perform daily activities independently. These results are similar to the aforementioned results. High concordance was found between PTs and Ms in terms of expectations from therapies. However, $67.72 \%$ of the Ms and $81.5 \%$ of the PTs considered alternative treatment methods to be necessary (Table 3).

The importance of a high education level of families for adequate care and treatment of a disabled child is known. In studies investigating the relations between families and health teams in early and later periods, Ms stated that they did not understand the explanations their child's disease $^{23,24)}$. In our study, $83.1 \%$ of Ms had 12 years of education or less (Table 1).

Insignificant concordance was found between PTs and Ms regarding the expectations from treatments. We consider that this resulted from the fact that families are not sufficiently informed about their child's health and treatments or that they cannot understand enough of the information they are given.

Taaniala et al. emphasized that having enough knowledge about the condition of the child is important for adaptation to the child and care, education, and rehabilitation of the child ${ }^{25}$.

One of the most important factors that positively affects the ability to cope with difficulties is education ${ }^{26)}$. In the study of Singer et al. conducted with families of disabled children, families with a higher education level reportedly cared for their children better; in other words, awareness about the disease was higher ${ }^{27}$ ). In our study, the concordance between Ms and PTs regarding the appropriateness of therapy was $82.3 \%$, and it was found to be $36.2 \%$ for treatment awareness. These concordance rates show the importance of informing and educating the mothers of children with $\mathrm{CP}$.

In conclusion, participation of the Ms in the treatment program and awareness about the treatment are important. We consider that health staff involved in the care of disabled children should consider the opinions of the Ms about the therapy when determining the most appropriate and most beneficial treatment.

We consider that Ms should cooperate with PTs in the course of rehabilitation and receive education about the condition of their children in order to increase their awareness of their child's disease, find the most appropriate treatment option, practice the therapy at home in the most effective and most appropriate way, and obtain better results from rehabilitation programs.

\section{REFERENCES}

1) King GA, Rosenbaum PL, King SM: Evaluating family-centred service using a measure of parents' perceptions. Child Care Health Dev, 1997, 23: 47-62. [Medline] [CrossRef]

2) Hostler SL: Pediatric family-centered rehabilitation. J Head Trauma Rehabil, 1999, 14: 384-393. [Medline] [CrossRef]

3) King G, King S, Rosenbaum P, et al.: Family-centered caregiving and well-being of parents of children with disabilities: linking process with outcome. J Pediatr Psychol, 1999, 24: 41-53. [CrossRef]

4) Kavlak E, Cavlak U: Exploring the meaning of cerebral palsy and its treatment: a preliminary prospective study related to the perceptions of mothers and physical therapist in Turkey. European Academy of childhood Disability 23rd Annual Meeting, 2011 June 8-11; Rome- Italy.

5) Knox V: Do parents of children with cerebral palsy express different concerns in relation to their child's type of cerebral palsy, age and level of disability? Physiotherapy, 2008, 94: 56-62. [CrossRef]

6) Dunst CJ, Johanson C, Trivette CM, et al.: Family-oriented early intervention policies and practices: family-centered or not? Except Child, 1991, 58: 115-126. [Medline]

7) King G, Law M, King S, et al.: Parents' and service providers' perceptions of the family-centredness of children's rehabilitation services. Phys Occup Ther Pediatr, 1998, 18: 21-40. [CrossRef]

8) King S, Teplicky R, King G, et al.: Family-centered service for children with cerebral palsy and their families: a review of the literature. Semin Pediatr Neurol, 2004, 11: 78-86. [Medline] [CrossRef]

9) King G, King S, Rosenbaum P: Interpersonal aspects of care-giving and 
client outcomes: a review of the literature. Ambul Child Health, 1996, 2 : 151-160.

10) Jahnsen R, Aamodt G, Rosenbaum P: Gross Motor Function Classification System used in adults with cerebral palsy: agreement of self-reported versus professional rating. Dev Med Child Neurol, 2006, 48: 734-738. [Medline] [CrossRef]

11) McCormick A, Brien M, Plourde J, et al.: Stability of the Gross Motor Function Classification System in adults with cerebral palsy. Dev Med Child Neurol, 2007, 49: 265-269. [Medline] [CrossRef]

12) Clubb RL: Chronic sorrow: adaptation patterns of parents with chronically ill children. Pediatr Nurs, 1991, 17: 461-466. [Medline]

13) Fraley AM: Chronic sorrow: a parental response. J Pediatr Nurs, 1990, 5 : 268-273. [Medline]

14) Futcher JA: Chronic illness and family dynamics. Pediatr Nurs, 1988, 14: 381-385. [Medline]

15) Hirose T, Ueda R: Long-term follow-up study of cerebral palsy children and coping behaviour of parents. J Adv Nurs, 1990, 15: 762-770. [Medline] [CrossRef]

16) Mc Cubbin MA: Family strengeths in the care of handicapped children: targets for intervention. Fam Relat, 1989, 38: 436-442. [CrossRef]

17) Gümüşcü Ş, Pişkin Ü: Otistik bir çocuğun ve ailesinin kısa süreli eğitim programlarından sağladıkları yarar: bir vaka sunumu. Turk Psikoloji Dergisi, 1994, 9: 30-34.

18) Krawetz S, Katz S: A Goal directed approach to training parents of children whith a developmental disability. Br J Ment Subnorm, 1990, 36: $17-$ 29.

19) Law M, King G: Parent compliance with therapeutic interventions for children with cerebral palsy. Dev Med Child Neurol, 1993, 35: 983-990.
[Medline] [CrossRef]

20) Lambrenos K, Weindling AM, Calam R, et al.: The effect of a child's disability on mother's mental health. Arch Dis Child, 1996, 74: 115-120. [Medline] [CrossRef]

21) Gilbride DD: Parental attitudes toward their child with a disability: implication rehabilitation counselors. Rehabil Couns Bull, 1993, 36: 139-141.

22) Karaduman AA, Yılmaz ÖT: Türkiyenin Farklı Bölgelerinde Fizyoterapi Hizmeti Alan Çocuk Özürlülerin Fonksiyonel Düzeyini Ve Yaşam Kalitelerini Artırmaya Yönelik Aile Eğitiminin Katkısının İncelenmesi. Tübitak Tarafından Sosyal Ve Beşeri Araştırmalar Grubu (SOBAG) 104K113 1010, 2010.

23) Donovan TJ, Reddihough DS, Court JM, et al.: Health literature for parents of children with cerebral palsy. Dev Med Child Neurol, 1989, 31: 489-493. [Medline] [CrossRef]

24) McKay M, Hensey O: From the other side: parents' views of their early contacts with health professionals. Child Care Health Dev, 1990, 16: 373 381. [Medline] [CrossRef]

25) Taanila A, Syrjälä L, Kokkonen J, et al.: Coping of parents with physically and/or intellectually disabled children. Child Care Health Dev, 2002, 28: 73-86. [Medline] [CrossRef]

26) Yıldırım F, Conk Z: Zihinsel Yetersizliği Olan Çocuğa Sahip Anne/ Babaların Stresle Basa Cıkma Tarzlarına ve Depresyon Düzeylerine Planlı Eğitimin Etkisi. Cumhuriyet Universitesi Hemsirelik Yuksekokulu Derg, 2005, 9: 1-10.

27) Singer GH, Irvin LK, Hawkins N: Stress management training for parents of children with severe handicaps. Ment Retard, 1988, 26: 269-277. [Medline] 